Vol.2, No. 1, Jan. 2019

\title{
PENGARUH MANAJEMEN LABA DAN RASIO LIKUIDITAS TERHADAP AGRESIVITAS PAJAK
}

\author{
Mar atun Kariimah*), Rini Septiowati \\ Universitas Pamulang \\ *Email :rini_adidaya@yahoo.com
}

\begin{abstract}
This study aims to determine how much influence the effect of management profit and liquidity ratio against tax aggressiviness. The method used is descriptive quantitative and types of data used is secondary data. The population in this study are all manufacturing companies sector consumer goods listed in Indonesia stock Exchange in 2012-2016. the sampling method of this research is purposive sampling with total sample in this study was 45 data and this study using SPSS versi 22. Based on the result of the study, it shows that partial management profit has negative and no significant effect on tax aggressiveness. Liquidity ratio partially has significant effect the tax aggressiveness. Simultaneously the variabel of management profit and liquidity ratio have significant against tax aggressiveness.
\end{abstract}

Keywords : Management profit, liquidity ratio, and tax aggressiveness.

\begin{abstract}
Abstrak
Penelitian ini bertujuan untuk menguji pengaruh Manajemen Laba dan Rasio Likuiditas terhadap Agresivitas Pajak. Penelitian ini merupakan jenis penelitian kuantitatif dengan menggunakan data sekunder. Populasi dalam penelitian ini adalah perusahaan manufaktur sektor barang konsumsi yang terdaftar di Bursa Efek Indonesia periode tahun 2012-2016. Sampel menggunakan metode purposive sampling dengan total sampel sebanyak 45 data dan Penelitian ini menggunakan SPSS 22. Berdasarkan hasil penelitian ini, menunjukkan bahwa Manajemen Laba secara parsial berpengaruh negatif dan tidak signifikan terhadap Agresivitas Pajak. Rasio Likuiditas secara parsial berpengaruh signifikan terhadap Agresivitas Pajak. Secara simultan (bersama-sama) variabel Manajemen Laba dan Rasio Likuiditas berpengaruh signifikan terhadap Agresivitas Pajak.
\end{abstract}

Kata kunci : Manajemen Laba, Rasio Likuiditas, dan Agresivitas Pajak 
Vol.2, No. 1, Jan. 2019

\section{PENDAHULUAN}

Indonesia merupakan negara berkembang yang sangat membutuhkan dana untuk pembangunan. Salah satu dana pembangunan tersebut didapat dari sumber pendapatan negara yaitu pajak. Bagi negara, pajak merupakan unsur penting untuk menopang anggaran pengeluaran negara yang bertujuan untuk meningkatkan kesejahteraan rakyat. Ternyata usaha-usaha tersebut masih belum cukup untuk memenuhi target penerimaan pajak dalam beberapa tahun terakhir ini. Sebagai salah satu Wajib Pajak, perusahaan mempunyai kewajiban untuk melakukan pembayaran pajak sebagaimana yang telah diatur dalam undang-undang dinyatakan dalam pasal 23A Amandemen UUD 1945 (Pajak dan pungutan lainnya yang bersifat memaksa untuk keperluan negara diatur dengan undang-undang). Namun, setiap perusahaan mempunyai kepentingannya sendiri-sendiri terutama perusahaan yang berorientasi pada laba. Jenis ini mempunyai tujuan untuk memaksimalkan laba perusahaan guna meningkatkan kekayaan perusahaan.

Menurut frank et al. dalam hariyati (2016:29) Agresivitas Pajak merupakan suatu tindakan merekayasa pendapatan kena pajak yang dirancang melalui tindakan perencanaan pajak (tax planing) baik menggunakan cara yang tergolong legal (tax avoidance) atau ilegal (tax evasion). Walau tidak semua tindakan yang dilakukan melanggar peraturan, namun semakin banyak celah yang digunakan maka perusahaan tersebut dianggap semakin agresif terhadap pajak. Tindakan manajemen yang merencanakan untuk memperkecil pajak perusahaan dengan cara melakukan pajak agresif kini menjadi hal yang umum dikalangan perusahaan. Fenomena penghindaran pajak ini terjadi di sebuah perusahaan yang bergerak di bidang jasa kesehatan terafiliasi perusahaan di Singapura, yakni PT RNI, kini tengah menjalani proses pemeriksaan oleh Kantor Wilayah Direktorat Jenderal Pajak (DJP) Jakarta Khusus. Perusahaan tersebut diduga melakukan upaya-upaya penghindaran pajak, padahal memiliki aktivitas cukup banyak di Indonesia yakni di Jakarta, Solo, Semarang, dan Surabaya.

Manajemen laba merupakan tindakan manajer untuk melaporkan laba yang dapat memaksimalkan kepentingan pribadi atau perusahaan dengan menggunakan kebijakan akuntansi. Laba yang berkualitas adalah laba yang dapat mencerminkan kelanjutan laba dimasa depan, yang ditentukan oleh komponen akrual dan aliran kasnya. Manajer selalu berusaha agar laba perusahaan terlihat lebih rendah daripada laba yang sesungguhnya diperoleh. Upaya ini dilakukan untuk meminimalisir beban pajak yang akan ditanggung oleh perusahaan. Penelitian ini menggunakan effective tax rate (ETR) sebagai proksi pengukuruan agresivitas pajak perusahaan. ETR dianggap mampu merefleksikan perbedaan antara perhitungan laba buku dengan laba fiskal. Pemilihan perusahaan manufaktur sebagai sampel dikarenakan industri ini memiliki berbagai sub sektor salah satunya sub sektor barang konsumsi diharapkan dapat mewakili sektor-sektor lainnya.

Berdasarkan uraian diatas peneliti tertarik untuk menganalisis hubungan ketiga variabel yaitu "Pengaruh Manajemen Laba dan Rasio Likuiditas Terhadap Agresivitas Pajak (Studi Empiris Pada Perusahaan Manufaktur Sektor Barang Konsumsi Yang terdaftar Di Bursa Efek Indonesia Tahun 2012-2016)” 


\section{Perumusan Masalah}

Berdasarkan uraian yang telah dijelaskan diatas, maka penulis merumuskan permasalahan sebagai berikut :

1. Apakah Manajemen Laba berpengaruh terhadap Agresivitas Pajak ?

2. Apakah Rasio Likuiditas berpengaruh terhadap Agresivitas Pajak ?

3. Apakah Manajemen Laba \& Rasio Likuiditas berpengaruh terhadap Agresivitas Pajak secara simultan?

\section{Tujuan Penelitian}

1. Untuk mengetahui dan memberikan bukti secara empiris pengaruh Manajemen Laba terhadap Agresivitas Pajak.

2. Untuk mengetahui dan memberikan bukti secara empiris pengaruh Rasio Likuiditas terhadap Agresivitas Pajak.

3. Untuk mengetahui dan memberikan bukti secara empiris pengaruh Manajemen Laba \& Rasio Likuiditas terhadap Agresivitas Pajak secara simultan.

\section{TINJAUAN PUSTAKA}

\section{Teori Agensi (Agency Teory)}

Menurut belkaoui (2007:188) teori agensi berawal dengan adanya penekanan pada kontrak sukarela yang timbul diantara berbagai pihak organisasi sebagai suatu solusi yang efisien terhadap konflik kepentingan tersebut. hubungan agensi sebagai sebuah kontrak antara seseorang atau lebih meminta orang lain untuk melakukan jasa tertentu demi kepentingannya. Untuk itu orang ini atau pemilik perusahaan akan mendelegasikan wewenang untuk mengerjakan sesuatu yang seharusnya dilakukannya kepada orang lain yang dipilihnya atau disebut dengan manajer. Teori keagenan merupakan teori yang menyatakan adanya konflik kepentingan antara pihak manajer dengan pihak pemilik, dimana masingmasing pihak memiliki tujuan yang berbeda sehingga setiap pihak akan melakukan tindakan yang berbeda sesuai dengan tujuan masing-masing.

Negara Indonesia sistem yang dianut adalah self assessment yaitu memberikan wewenang kepada perusahaan untuk menghitung dan melaporkan pajaknya sendiri. Penggunaan sistem tersebut tentu dapat memberikan kesempatan bagi pihak agent untuk memanipulasi data mengenai pendapatan kena pajak menjadi lebih rendah sehingga beban pajak yang ditanggung perusahaan semakin kecil. Teori agensi sangat berkaitan dengan tindakan manajemen laba dan agresivitas pajak yang dilakukan perusahaan.

\section{Definisi dan Unsur Pajak}

Definisi Pajak yang dikemukakan oleh para ahli, adalah sebagai berikut Agoes dan Trisnawati (2013:6):

1. Menurut Prof. Dr. Rochmat Soemitro, SH 
"Pajak adalah iuran rakyat kepada kas negara berdasarkan undang-undang (yang dapat dipaksakan) dengan tidak mendapat jasa timbal (kontraprestasi) yang langsung dapat ditujukan, dan yang digunakan untuk membayar pengeluaran umum".

2. Menurut Prof. Dr. P.J.A Andriani

"Pajak adalah iuran kepada Negara, yang dapat dipaksakan dan terhutang oleh yang wajib membayarnya menurut peraturan, dengan tidak mendapat prestasi kembali, yang langsung dapat ditunjuk, dan yang gunanya adalah untuk membiayai pengeluaran umum berhubungan dengan tugas negara untuk menyelenggarakan pemerintahan."

Dari beberapa definisi tersebut dapat disimpulkan bahwa pajak memiliki beberapa unsur (Mardiasmo, 2011:1), yaitu:

1. Iuran dari rakyat kepada negara.

Yang berhak memungut pajak hanyalah negara. Iuran tersebut berupa uang (bukan barang).

2. Berdasarkan undang-undang.

Pajak dipungut berdasarkan atau dengan kekuatan undang-undang serta aturan pelaksanaannya.

3. Tanpa jasa timbal atau kontraprestasi dari negara yang secara langsung dapat ditunjuk. Dalam pembayaran pajak tidak dapat ditunjukkan adanya kontraprestasi individual oleh pemerintah.

4. Digunakan untuk membiayai rumah tangga negara, yakni pengeluaranpengeluaran yang bermanfaat bagi masyarakat luas.

\section{Manajemen Laba}

Menurut Harahap (2011:309) laba adalah perbedaan antara revenue yang direalisasi yang timbul dari transaksi pada periode tertentu dihadapkan dengan biaya-biaya yang dikeluarkan pada periode tersebut. Laba merupakan informasi penting dalam suatu laporoan keuangaan.

Sulistyanto (2014:6) mengungkapkan Manajemen laba adalah upaya manajer perusahaan untuk mengintervensi atau mempengaruhi informasiinformasi dalam laporan keuangan dengan tujuan untuk mengelabui stake holder yang ingin mengetahui kinerja dan kondisi perusahaan. Pihak manajemen memiliki wewenang untuk memilih opsi dan aturan-aturan yang diterapkan dalam perlakuan akuntansi. Melalui wewenang tersebut memberikan keleluasaan bagi manajemen dalam mengelola laba perusahaan yang tercantum dalam laporan keuangan sesuai dengan kepentingannya, yaitu memperoleh insentif dari hasil kinerjanya yang diukur dari besarnya laba yang dicapai

\section{Strategi Melakukan Manajemen Laba}

Harley dalam Yuliana (2016:27) menyatakan bahwa terdapat tiga strategi untuk melakukan manajemen laba, yaitu :

1. Meningkatkan Laba (Increasing income)

Salah satu strategi manajemen laba adalah meningkatkan laba yang dilaporkan pada periode kini untuk membuat perusahaan dipandang lebih 
baik. Cara ini juga memungkinkan peningkatan laba selama beberapa periode.

2. Mandi Besar (big bath)

Strategi mandi besar dilakukan melalui penghapusan sebanyak mungkin pada suatu periode. Periode yang dipilih biasanya periode dengan kinerja yang buruk atau peristiwa saat terjadi satu kejadian yang tidak biasa seperti perubahan manajemen, merger atau restrukturisasi.

3. Perataan laba (income smoothing)

Perataan laba merupakan bentuk umum manajemen laba. Pada strategi ini, manajer meningkatkan atau menurunkan laba yang dilaporkan untuk mengurangi fluktuasinya. Perataan laba juga mencakup tidak melaporkan bagian laba pada periode baik dengan menciptakan cadangan atau "bank" laba dan kemudian melaporkan laba ini saat periode buruk.

\section{Rasio Likuiditas}

Rasio likuiditas menggambarkan kemampuan perusahaan untuk menyelesaikan kewajiban jangka pendeknya. Kewajiban jangka pendek tersebut seperti membayar tagihan listrik, gaji pegawai, atau hutang yang telah jatuh tempo .Likuiditas tidak hanya berkaitan dengan keadaan keseluruhan keuangan perusahaan, tetapi juga berkaitan dengan kemampuannya merubah aktiva lancar tertentu menjadi kas. Menurut sartono (2015:116) Rasio likuiditas menunjukan kemampuan untuk membayar kewajiban finansial jangka pendek tepat pada waktunya. Likuiditas perusahaan ditentukan oleh besar kecilnya aktiva lancar yaitu aktiva yang mudah untuk diubah menjadi kas yang meliputi kas, surat berharga, piutang, persediaan. Suatu perusahaan harus mempertahankan sumber kas yang mencukupi untuk membayar seluruh tagihannya yang sah pada saat tagihan jatuh tempo. Perusahaan yang tidak dapat mempertahankannya akan mengalami kesulitan likuiditas dan berada dalam kondisi keuangan yang sangat serius. Ironisnya, kondisi ini dapat saja terjadi meskipun perusahaan menghasilkan laba yang besar.

Tingkat likuiditas antara perusahaan satu dengan yang lain berbeda-beda. Investor menilai suatu perusahaan salah satunya dengan menggunakan rasio likuiditas yang angka-angkanya dapat diperoleh melalui laporan neraca perusahaan. Semakin tinggi nilai rasionya maka perusahaan akan semakin diminati oleh investor.

\section{Tujuan dan manfaat likuiditas}

Rasio likuiditas mempunyai banyak manfaat untuk pihak yang berkepentingan terhadap perusahaan. Pihak yang paling berkepentingan dalam hali ini adalah pemilik perusahaan dan manajemen perusahaan guna menilai kemampuan perusahaan itu sendiri. Selain itu pihak berkepentingan lainnya kreditor dan investor untuk mengetahui seberapa likuid perusahaannya. Perhitungan rasio likuiditas tidak hanya berguna bagi perusahaan namun juga bagi pihak luar perusahaan.

Ada beberapa tujuan dan manfaat yang dapat diambil dari rasio likuiditas, yaitu : 
1. Untuk mengukur kemampuan perusahaan membayar kewajiban jangka pendek dengan aktiva lancar secara keseluruhan.

2. Untuk mengukur seberapa besar uang kas yang tersedia untuk membayar hutang.

3. Untuk melihat kelemahan yang dimiliki perusahaan dari masing-masing komponen yang ada diaktiva lancar dan utang lancar.

4. Sebagai alat perencanaan kedepan, terutama yang berkaitan dengan perencanaan kas dan hutang.

5. Untuk mengukur kemampuan perusahaan membayar kewajiban atau utang yang sudah waktunya dibayar sesuai batas waktu yang ditentukan.

6. Menjadi tolak ukur bagi pihak manajemen untuk memperbaiki kinerjanya, dengan melihat rasio likuiditas yang ada pada saat ini.

\section{Agresivitas Pajak}

Agresivitas pajak merupakan hal yang sangat umum saat ini diperusahaanperusahaan besar di seluruh dunia. Bagi perusahaan pajak dianggap sebagai beban yang akan mengurangi keuntungan perusahaan. Hal itu menyebabkan perusahaan mencari cara untuk mengurangi biaya pajak, Oleh karena itu dimungkinkan perusahaan akan menjadi agresif dalam perpajakan Semakin banyak celah yang digunakan maka perusahaan tersebut dianggap semakin agresif. Adapun faktor yang memotivasi wajib pajak untuk melakukan agresivitas pajak menurut (suandy 2011:2) antara lain :

1) Jumlah pajak yang harus dibayar.

Semakin besar pajak yang harus dibayar, semakin besar juga kecenderungan wajib pajak untuk melakukan pelanggaran.

2) Besar sanksi

Semakin ringan sanksi yang dikenakan terhadap pelanggaran, maka semakin besar kecenderungan wajib pajak untuk melakukan pelanggaran.

3) Kemungkinan untuk terdeteksi.

Semakin kecil kemungkinan suatu pelanggaran terdeteksi maka semakin besar kecenderungan wajib pajak untuk melakukan pelanggaran.

4) Biaya untuk menyuap fiskus.

Semakin kecil biaya untuk menyuap fiskus, semakin besar kecenderungan wajib pajak untuk melakukan pelanggaran.

\section{Keuntungan dan Kerugian Agresivitas Pajak}

Dalam melakukan pajak agresif, perusahaan pasti mempertimbangkan biaya dan manfaat yang akan diterima. Keuntungan utama yang jelas diperoleh Adalah terdapat penurunan beban pajak. Menurut Chen et al. Dalam putri (2014:30) Ada tiga keuntungan yang diperoleh dari tindakan pajak agresif yaitu :

1. Terdapat penghematan pajak yang dibayarkan perusahaan kepada negara, sehingga porsi yang dinikmati pemilik atau pemegang saham menjadi lebih besar.

2. Terdapat bonus atau kompensasi yang mungkin diberikan pemilik atau pemegang saham kepada manajer atas tindakan pajak agresif yang telah 
dilakukannya dan menjadi keuntungan tersendiri bagi pemilik atau pemegang saham.

3. Terdapat kesempatan bagi manajer untuk melakukan rent extraction, yakni tindakan manajer yang tidak memaksimalkan kepentingan pemilik. Hal ini dapat berupa penyusunan laporan keuangan yang agresif, pengambilan sumber daya atau aset perusahaan untuk kepentingan pribadi.

Ada keuntungan pasti ada kerugian, ada biaya atau kerugian yang mungkin timbul akibat agresivitas pajak yang dilakukan. Tindakan pajak agresif dapat dilakukan melalui perencanaan pajak, baik menggunakan cara yang tergolong atau tidak tergolong (tax evasion). Saat tindakan pajak agresif ditemukan ditempuh melalui cara yang tergolong tax evasion atau disebabkan karena terdapat ketidakpatuhan pada peraturan, perusahaan harus menerima saksi yang dikenakan oleh otoritas perpajakan. Atas sanksi ini perusahaan harus menanggung reputational dan political cost.

Kerugian dari tindakan pajak agresif yaitu:

1) Kemungkinan perusahaan mendapat sanksi/ penalti dari fiskus pajak, dan turunnya harga saham perusahaan.

2) Penurunan harga saham dikarenakan pemegang saham lainnya mengetahui tindakan pajak agresif yang dijalankan manajer dilakukan dalam rangka rent extraction.

3) Rusaknya reputasi perusahaan akibat audit dari fiskus pajak.

Keuntungan dan kerugian dari agresivitas pajak ini membuat manajer sebagai pembuat keputusan perusahaan harus memperhitungkan tindakan yang diambilnya. Bila keputusan yang diambil oleh manajer menyebabkan kerugian, maka dapat menyebabkan konflik antar pemilik perusahaan atau pemegang saham dan manajer.

\subsection{Kerangka Pemikiran}

Untuk mempermudah penulis guna melakukan penelitian, maka dibawah ini dapat digambarkan kerangka pemikiran skripsi yang disajikan dalam bentuk bagan yang berkaitan dengan permasalahan penelitian.

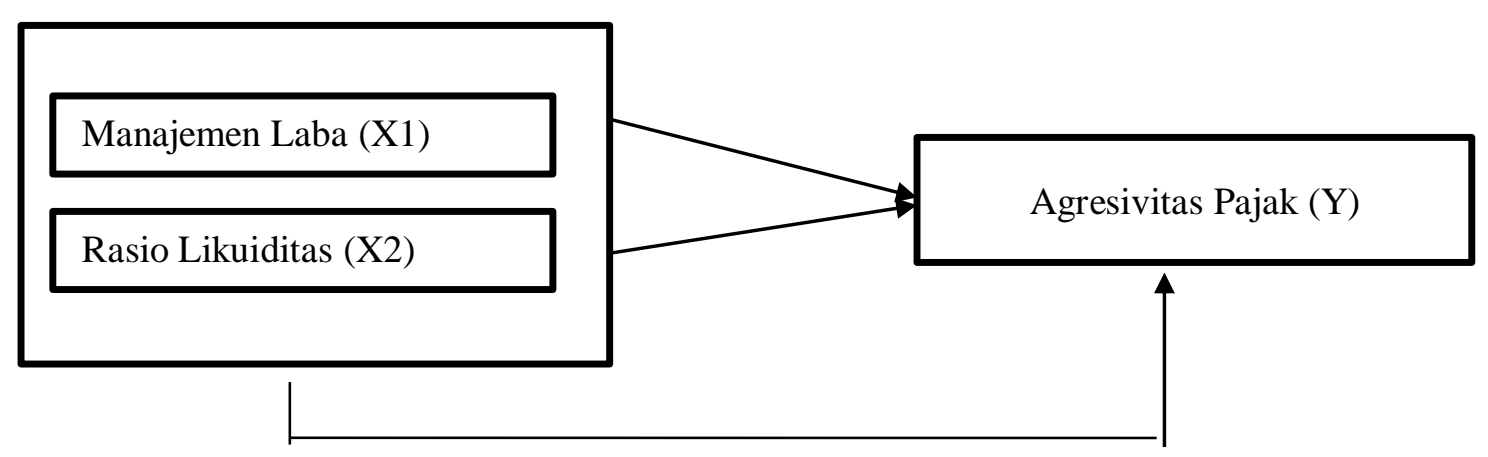

Gambar 2.1

Kerangka Pemikiran 


\section{Pengembangan Hipotesis}

$\mathrm{H}_{1}$ : Manajemen Laba mempunyai pengaruh terhadap Agresivitas Pajak

$\mathrm{H}_{2}$ : Rasio Likuiditas mempunyai pengaruh terhadap Agresivitas Pajak

$\mathrm{H}_{3}$ : Manajemen Laba dan Rasio Likuiditas mempunyai pengaruh terhadap Agresivitas Pajak secara simultan

\section{METODOLOGI PENELITIAN}

\section{Jenis Penelitian}

Dalam penelitian ini penulis menyusun tulisan yang bersifat kuantitatif yaitu penelitian yang dilakukan dengan cara melakukan adanya pengaruh variabel independen terhadap variabel dependen berbentuk angka. Sumber data yang diambil dalam penelitian ini adalah data sekunder perusahaan manufaktur industri barang konsumsi dari Bursa Efek Indonesia. Penelitian ini berkaitan dengan pengaruh dari variabel independen, meliputi : Manajemen Laba \& Rasio Likuiditas terhadap variabel dependennya yaitu Agresivitas Pajak.

\section{Lokasi Penelitian}

Pada Penelitian ini penulis memperoleh data melalui situs website: www.idx.co.id. Tahun penelitian yang diambil dari tahun 2012-2016 pada perusahaan manufaktur industri barang konsumsi yang terdaftar di Burse Efek Indonesia.

\section{Variabel Dan Pengukuran}

Operasional variabel adalah pengertian variabel secara operasional, secara praktik, secara nyata dalam lingkup objek penelitian/objek yang diteliti (Deviana,39,2017). Dalam penelitian ini terdapat dua variabel yaitu variabel independen dan dependen.Variabel independen adalah variabel yang menjadi penyebab terjadinya atau terpengaruhnya variabel dependen. Variabel independen dalam penelitian ini adalah manajemen laba dan Rasio Likuiditas.

Manajemen laba merupakan metode yang digunakan manajemen untuk memodifikasi laba perusahaan sesuai dengan keinginannya. Manajemen Laba adalah perilaku manajer dalam pengungkapan laporan keuangan yaitu dengan meningkatkan (menurunkan) laba yang akan menguntungkan dirinya (Yulianti,2005:18) .

Rumus yang digunakan dalam penelitian ini adalah rumus yang diukur dengan pendekatan distribusi laba yaitu :

Keterangan :

$$
\Delta \mathrm{E}=\frac{\text { Eit }-\mathrm{Eit}-1}{\mathrm{MVEt}-1}
$$

$\Delta \mathrm{E}=$ Distribusi laba bila nilai $\mathrm{E}$ adalah nol atau positif, maka perusahaan menghindari penurunan laba. Bila nanti $\mathrm{E}$ adalah negatif, maka perusahaan menghindari pelaporan kerugian. Pada penelitian ini, nilai 
dari E tersebut hanya digunakan sebagai informasi tambahan pada statistik deskriptif.

$\mathrm{E}_{\mathrm{it}} \quad=$ Laba perusahaan $\mathrm{i}$ pada tahun $\mathrm{t}$

$\mathrm{E}_{\mathrm{it}-1} \quad=$ Laba perusahaan $\mathrm{i}$ pada tahun $\mathrm{t}-1$

$\mathrm{MVE}_{\mathrm{t}-1}=$ Market Value of Equity perusahaan i pada tahun ${ }_{\mathrm{t}-1}$ (menggunakan nilai kapitalisasi pasar). Nilai kapitalisasi pasar diukur dengan mengalikan jumlah saham beredar perusahaan i pada akhir tahun ${ }_{\mathrm{t}-1}$ dengan harga saham perusahaan i pada akhir tahun $\mathrm{t}$.

Rasio ini untuk mengukur kemampuan perusahan dalam membanyar kewajiban jangka pendek atau utang yang segera jatuh tempo pada saat ditagih secara keseluruhan (Kasmir, 2008: 134). Rumus yang digunakan dalam penelitian ini adalah:

$$
C R=\frac{\text { Aktiva Lancar }}{\text { Utang Lancar }}
$$

Variabel dependen adalah variabel yang nilainya dipengaruhi oleh variabel independen. Variabel dependen dalam penelitian ini adalah agresivitas pajak. Agresivitas pajak merupakan keinginan Wajib Pajak (WP) untuk meminimalkan beban pajak yang dibayar dengan cara yang legal, illegal maupun kedua-duanya. Adapun proksi utama yang digunakan dalam penelitian ini adalah Effective Tax Rate (ETR) yang dihitung dari:

$$
E T R=\frac{\text { Beban Pajak Penghasilan }}{\text { Pendapatan sebelum Pajak }}
$$

ETR menggambarkan persentase total pajak penghasilan yang sesungguhnya dibayarkan perusahaan dari total pendapatan sebelum pajak yang diperoleh, dilihat dari laporan arus kas perusahaan. Semakin rendah ETR yang dimiliki perusahaan (mendekati 0), maka semakin agresif suatu perusahaan terhadap pajak penghasilan yang harus dibayarkan.

Tabel 3.1

\section{Operasional Variabel}

\begin{tabular}{|c|c|c|}
\hline Variabel & Indikator & $\begin{array}{c}\text { Skala Ukur } \\
\text { Data }\end{array}$ \\
\hline $\begin{array}{c}\mathrm{X}_{1}=\text { Manajemen } \\
\text { Laba }\end{array}$ & $\Delta \mathrm{E}=\frac{\text { Eit }- \text { Eit }-1}{\text { MVEt }-1}$ & Rasio \\
\hline $\begin{array}{c}\mathrm{X}_{2}=\text { Rasio } \\
\text { Likuiditas }\end{array}$ & $C R=\frac{\text { Aktiva Lancar }}{\text { Utang Lancar }}$ & Rasio \\
\hline $\begin{array}{c}\text { Y=Agresivitas } \\
\text { Pajak }\end{array}$ & $E T R=\frac{\text { Beban Pajak Penghasilan }}{\text { Laba Sebelum Pajak }}$ & Rasio \\
\hline
\end{tabular}




\section{Populasi Dan Sampel}

Populasi dalam penelitian ini adalah perusahaan manufaktur industri barang konsumsi yang terdaftar di Bursa Efek Indonesia (BEI) selama tahun 2012 sampai dengan tahun 2016. Peneliti memilih perusahaan sektor konsumsi yang menerbitkan laporan keuangan tahunan yang diaudit dan dipubliskan diBursa Efek Indonesia selama periode tahun 2012-2016 yang tidak mengalami kerugian serta disajikan dalam mata uang rupiah.

Metode pengumpulan sampel yang digunakan dalam penelitian ini adalah metode purposive sampling. Metode purposive sampling adalah teknik pengambilan sampel pada populasi tertentu yang telah memenuhi kriteria yang ditentukan peneliti, yang bertujuan untuk mendapatkan hasil yang akurat. Kriteria-kriteria dalam pengambilan sampel dalam penelitian ini adalah sebagai berikut :

1. Merupakan perusahaan manufaktur sektor konsumsi yang terdaftar di Bursa Efek Indonesia (BEI) selama periode 2012-2016.

2. Perusahaan yang memiliki data lengkap yang dibutuhkan dalam penelitian ini, meliputi laporan keuangan perusahaan dari tahun 2012-2016.

3. Perusahaan memiliki laba tahun berjalan dari tahun 2011-2016

4. Perusahaan yang memiliki kapitalisasi pasar periode 2011-2016

5. Perusahaan yang tidak mengalami kerugian sebelum pajak dalam periode 2012-2016

Tabel 3.2

Kriteria Penarikan sampel

\begin{tabular}{|l|l|c|c|}
\hline No & \multicolumn{1}{|c|}{ Kriteria } & Memenuhi kriteria & $\begin{array}{c}\text { Tidak } \\
\text { memenuhi } \\
\text { kriteria }\end{array}$ \\
\hline 1 & $\begin{array}{l}\text { Perusahaan manufaktur sektor konsumsi } \\
\text { yang terdaftar di BEI periode 2012-2016 }\end{array}$ & 37 \\
\hline 2 & $\begin{array}{l}\text { Perusahaan yang memilki data laporan } \\
\text { keuangan lengkap selama tahun 2012-2016 }\end{array}$ & 27 & 10 \\
\hline 3 & $\begin{array}{l}\text { Perusahaan yang memiliki laba tahun } \\
\text { berjalan dari tahun 2011-2016 }\end{array}$ & 23 \\
\hline 4 & $\begin{array}{l}\text { Perusahaan yang memiliki kapitalisasi pasar } \\
\text { periode 2011-2016 }\end{array}$ & 16 & 7 \\
\hline 5 & $\begin{array}{l}\text { Perusahaan yang tidak mengalami kerugian } \\
\text { sebelum pajak selama periode 2012-2016 }\end{array}$ & 9 & 75 \\
\hline & Jumlah sample & $9 \times 5$ tahun & \\
\hline
\end{tabular}

Sumber : Data yang diolah 2018

\section{Teknik Pengumpulan Data}

Metode pengumpulan data yang digunakan oleh penulis dalam penyusunan skripsi ini adalah:

1. Metode studi pustaka (Library research)

Penelitian kepustakaan dilakukan untuk memperoleh data yang bersifat teoritis dan dapat menunjang materi pembahasan penelitian. Cara 
mengumpulkan data ini bersumber dari literatur yang berupa buku , jurnal ilmiah dan literatur lainnya yang berhubungan dengan penyusunan skripsi.

2. Metode Dokumentasi

Penelitian ini dilakukan untuk mendapatkan data dan informasi yang dibutuhkan secara langsung dari objek penelitian. Metode pengumpulan data yang digunakan dalam penelitian ini adalah metode dokumentasi, yaitu dengan mengumpulkan data laporan keuangan berupa laporan tahunan (Annual report) Pada perusahaan manufaktur sektor konsumsi yang terdaftar di Bursa Efek Indonesia periode 2012-2016 .

\section{Teknik Analisis Data}

Penelitian yang diwujudkan ke dalam bentuk tesis ini menggunakan statistik sebagai alat analisis datanya. Teknik analisis data dimaksud diuraikan sebagai berikut: Statistik deskriptif, yaitu statistik yang bertujuan memberikan gambaran data masing-masing variabel penelitian. Uji yang digunakan adalah : Uji Normalitas, Uji Multikolinearitas, Uji Heteroskedasitas, Uji Autokorelasi, dan Uji Hipotesis dimana menggunakan Uji Persamaan Regresi dan Uji Korelasi.

\section{HASIL PENELITIAN DAN PEMBAHASAN}

Pasar modal telah hadir jauh sebelum Indonesia merdeka. Pasar modal atau Bursa Efek telah hadir sejak jaman kolonial belanda dan tepatnya pada tahun 1912 dibatavia. Pasar modal jaman ketika itu didirikan oleh pemerintah Hindia Belanda untuk kepentingan pemerintah atau VOC. Perkembangan dan pertumbuhan pasar modal tidak berjalan seperti yang diharapkan bahkan sempat vacum beberapa periode yang diakibatkan oleh beberapa faktor seperti perang dunia I dan II, Perpindahan kekuasaan dari pemerintah kolonial kepada pemerintah Republik Indonesia, dan kondisi laennya yang menyebabkan operasi Bursa Efek tidak dapat berjalan sebagaimana mestinya.

Pemerintah Indonesia mulai mengaktifkan pasar modal pada tahun 1977, dan beberapa tahun kemudian pasar modal mengalami pertumbuhan seiring dengan berbagai insentif dan regulasi yang dikeluarkan pemerintah. Secara singkat, tonggak perkembangan pasar modal Indonesia dapat dilihat sebagai berikut:

Data yang telah dikumpulkan berupa data laporan keuangan yang telah diaudit dari perusahaan manufaktur sektor barang konsumsi di Bursa Efek Indonesia periode 2012-2016. Pengolahan data pada penelitian ini menggunakan fasilitas elektronik dengan menggunakan SPSS Versi 22.0 untuk memudahkan pengolahan data sehingga dapat menjelaskan variabel-variabel yang diteliti. Jumlah seluruh populasi dalam penelitian ini adalah 37 perusahaan. Dari hasil sampel secara purposive sampling didapatkan hasil sampel berjumlah 9 perusahaan. Daftar sampel peneltian adalah sebagai berikut : 
Tabel 4.1

Daftar Sampel Penelitian

\begin{tabular}{|c|l|l|}
\hline NO & Kode & Nama Perusahaan \\
\hline 1. & KAEF & Kimia Farma Tbk. \\
\hline 2. & KLBF & Kalbe Farma Tbk. \\
\hline 3. & MERK & Merck Tbk. \\
\hline 4. & TSPC & Tempo Scan Pacific Tbk. \\
\hline 5. & DLTA & Delta Djakarta Tbk \\
\hline 6. & ROTI & Nippon Indosari Corpindo Tbk. \\
\hline 7. & GGRM & Gudang Garam Tbk. \\
\hline 8. & HMSP & H.M. Sampoerna Tbk. \\
\hline 9. & MLBI & Multi Bintang Indonesia Tbk \\
\hline
\end{tabular}

Sumber : www.idx.co.id

\section{Hasil Penelitian}

Metode analisis data yang dilakukan dalam penelitian ini adalah pengujian dilakukan dengan menggunakan software IBM SPSS versi 22.0. Dimana data tersebut dimasukkan kedalam data view pada software IBM SPSS 22.0 untuk dianalisis apakah Manajemen Laba dan Rasio Likuiditas dapat mempengaruhi Agresivitas Pajak secara parsial maupun simultan.

Dari hasil analisis statistik deskriptif ada beberapa variable yang digunakan dalam penelitian ini yaitu Manajemen Laba dan Rasio Likuiditas sebagai variabel bebas dan Agresivitas Pajak sebagai variabel terikat. Variabel tersebut telah diuji secara statistic seperti yang terlihat pada tabel 4.3 berikut ini:

Tabel 4.2

Hasil Uji Statistik Deskriptif Descriptive Statistics

\begin{tabular}{|l|l|l|l|l|l|}
\hline & $N$ & Minimum & Maximum & Mean & Std. Deviation \\
\hline ML & 45 &,- 04 &, 05 &, 0040 &, 01350 \\
L & 45 &, 51 & 7,60 & 3,0380 & 1,73356 \\
AP & 45 &, 21 &, 29 &, 2510 &, 01587 \\
Valid N (listwise) & 45 & & & & \\
\hline
\end{tabular}

Sumber : Hasil Output SPSS versi 22

Berdasarkan Hasil uji statistik deskriptif pada tabel di atas, yang menunjukan bahwa jumlah data masing-masing variabel yang diuji adalah sebanyak 45 perusahaan. Nilai minimum menggambarkan nilai paling kecil, nilai maximum menggambarkan nilai yang paling besar dan mean menggambarkan nilai rata-rata dari masing-masing variabel. Standar deviasi merupakan data statistik yang digunakan untuk menentukan bagaimana sebaran data dalam sampel dan seberapa dekat titik data kemean nilai sampel.

Variabel Manajemen Laba memiliki nilai minimum adalah -0,04 dan nilai maksimum sebesar 0,05 dengan nilai rata-rata adalah 0,0040 dan standar deviasinya sebesar 0.01350 . Hal ini mengindikasikan bahwa adanya penurunan laba sebesar $0,4 \%$ dari total aset tahun $\mathrm{t}-1$. 
Variabel Rasio likuiditas yang dihitung dengan menggunakan rasio lancar memiliki rata-rata 3,0380 yang menunjukan bahwa rata-rata sampel mampu menutupi setiap Rp. 1 kewajiban lancar perusahaan dengan 3,0380 aset lancar yang dimilikinya. nilai maximum atau tertinggi sebesar 7,60 yang mengindikasikan bahwa perusahaan tersebut dapat menutup setiap Rp.1 kewajiban lancar dengan Rp. 7.6 aset lancar.

Variabel Agresivitas Pajak yang dihitung menggunakan ETR memiliki nilai minimum 0,21 dan maksimum 0.29 dengan nilai rata-rata 0.2510 dan standar deviasi 0.01587 hal ini mengindikasikan bahwa beban rata-rata pajak perusahaan sampel adalah $25 \%$ dari laba sebelum pajak.

\section{Uji Asumsi Klasik}

\section{Uji Normalitas}

Uji normalitas data digunakan untuk mengetahui apakah data-data telah terdistribusi normal. Uji normalitas dalam penelitian ini menggunakan, Grafik normal probability plot, grafik histogram dan Kolmograv smirnov.

Berikut hasil uji normalitas dengan grafik sebagai berikut:

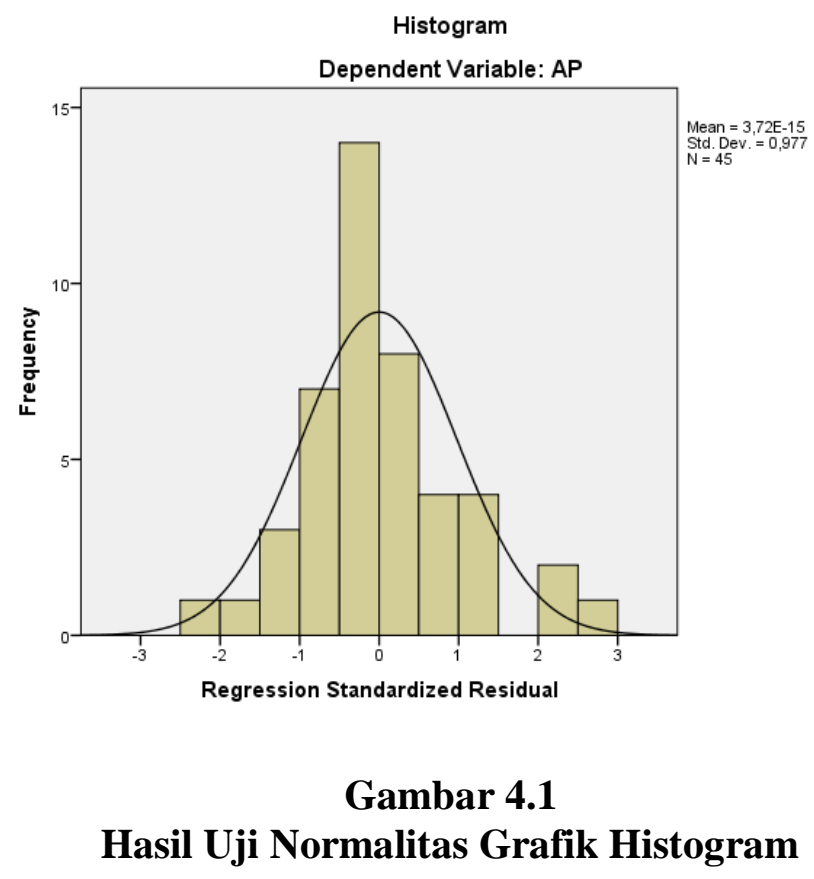

Dengan melihat gambar 4.1 dapat disimpulkan bahwa pada grafik histogram terlihat pola distribusi yang melenceng kekanan yang artinya adalah data terdistribusi normal. 
Vol.2, No. 1, Jan. 2019

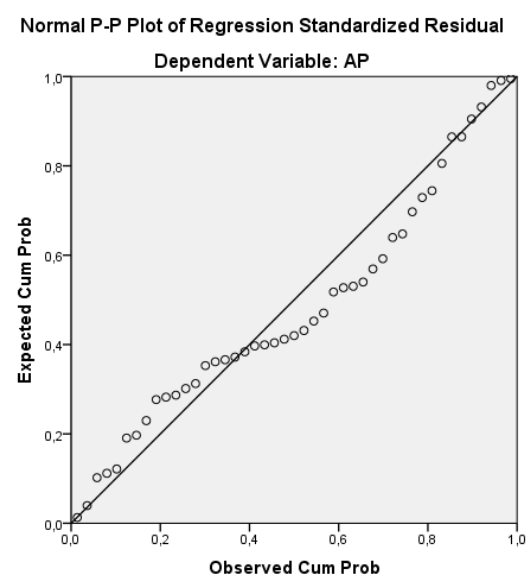

Gambar 4.2

Grafik Normal P-P Plot

Dengan melihat gambar Grafik normal probability plot dapat disimpulkan bahwa terlihat titik-titik menyebar disekitar grafik diagonal dan mengikuti arah garis diagonal. maka dapat disimpulkan model regresi dalam penelitian ini memenuhi asumsi normalitas.

Tabel 4.3

Uji Normalitas

One-Sample Kolmogorov-Smirnov Test

\begin{tabular}{|ll|l|}
\hline & & Unstandardized Residual \\
\hline$N$ & & 45 \\
Normal Parameters & Mean &, 0000000 \\
& Std. Deviation &, 01429807 \\
Most Extreme Differences & Absolute &, 126 \\
& Positive &, 126 \\
& Negative &,- 094 \\
Test Statistic & &, 126 \\
Asymp. Sig. (2-tailed) & &, $072^{c}$ \\
\hline
\end{tabular}

a. Test distribution is Normal.

b. Calculated from data.

c. Lilliefors Significance Correction.

Dasar dalam pengambilan keputusan uji normalitas Kolmogorov-smirnov adalah jika nilai signifikan asymp.sig (2-tailed) lebih besar dari alpha $(0,05)$ maka data terdistribusi normal dan jika angka signifikan asymp.sig (2-tailed) lebih kecil dari alpha $(0,05)$ maka data tidak terdistribusi secara normal. Besarnya nilai asymp.sig. (2-tailed) adalah 0,072 lebih besar dari pada alpha $(0,05)$, hal ini berarti data residual terdistribusi secara normal.

\section{Uji Mulitikolinearitas}

Uji ini bertujuan untuk menguji apakah pada model regresi ditemukan adanya korelasi antar variabel independen (bebas). Untuk mendeteksi ada 
tidaknya multikolonieritas dapat dilihat dari nilai tolerance dan variance inflation factor $(V I F)$. Hasil pengujian unutk masing-masing variabel adalah sebagai berikut:

Tabel 4.4

Uji Multikolinearitas

\begin{tabular}{|ll|l|l|}
\hline \multirow{2}{*}{ Model } & Collinearity Statistics \\
\cline { 3 - 4 } & Tolerance & VIF \\
\hline 1 & Constant) & \\
& ML & .997 & 1,003 \\
& L & .997 & 1,003 \\
\hline
\end{tabular}

a. Dependent Variable: AP

(Sumber : Hasil output SPSS Versi 22)

Berdasarkan hasil dari tabel 4.4 Maka dapat dilihat bahwa nilai tolerance manajemen laba 0,997, likuiditas 0,997. Pada kolom VIF hasil yang diperoleh manajemen laba 1,003 dan likuiditas 1,003. Angka-angka tersebut menunjukan bahwa tolerance lebih besar dari 0,1 dan VIF lebih kecil dari 10. Dengan demikian dapat disimpulkan bahwa tidak terjadi multikoloniearitas dalam model ini antar variabel independent.

\section{Uji Heteroskedastisitas}

Uji heteroskedastisitas bertujuan untuk menguji apakah nilai dalam model regresi terjadi ketidaksamaan variance residual satu pengamatan yang lain. Ada atau tidaknya heteroskedastisitas dalam penelitian ini adalah dengan cara melihat grafik plot nilai prediksi variabel dependen (ZPRED) dengan residualnya (SRESID). Model regresi yang baik adalah yang homoskedastisitas atau tidak terjadi heteroskedastisitas. Berikut ini adalah hasil pengujian heteroskedastisitas dengan grafik:

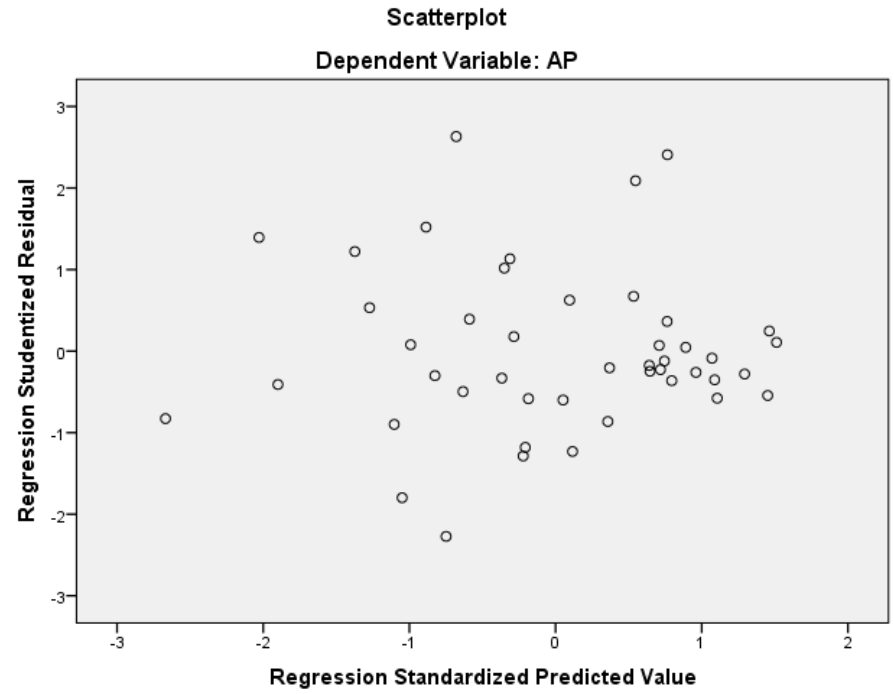

Sumber: data output SPSS versi 22

Gambar 4.3

Hasil Uji Heteroskedastisitas 
Dari gambar grafik scatterplot diatas terlihat bahwa titik-titik data menyebar dan tidak membentuk pola. Terlihat menyebar secara acak diatas maupun dibawah. Hal ini dapat disimpulkan pada penelitian ini tidak mengalami heteroskedastisitas pada model regresi.

\section{Uji Autokolerasi}

Uji ini bertujuan untuk menguji apakah dalam sebuah model regresi linear ada korelasi antara kesalahan pengganggu pada periode $t$ dengan kesalahan pada periode t-1 (sebelumnya). Jika terjadi korelasi, maka dinamakan ada masalah autokorelasi. Autokorelasi muncul karena observasinya yang berurutan sepanjang waktu berkaitan satu sama lainnya.

\section{Tabel 4.5}

\section{Uji Autokolerasi} Model Summary ${ }^{b}$

\begin{tabular}{|l|l|l|l|l|l|}
\hline Model & $R$ & $R$ Square & $\begin{array}{l}\text { Adjusted } \\
\text { Square }\end{array}$ & $\begin{array}{l}\text { Std. Error of the } \\
\text { Estimate }\end{array}$ & Durbin-Watson \\
\hline 1 &, $434^{a}$ &, 188 &, 150 &, 01463 & 1,895 \\
\hline
\end{tabular}

a. Predictors: (Constant), $L, M L$

b. Dependent Variable: AP

(Sumber : Hasil output SPSS Versi 22)

Berdasarkan tabel statistik Durbin Watson, dengan signifikasi 0,05 dan jumlah data $(\mathrm{n})=45$, serta $\mathrm{k}=2$ diperoleh nilai $\mathrm{dL}$ sebesar 1,4298 dan $\mathrm{dU}$ 1,6148. Dan hasil output diatas didapat nilai d yang dihasilkan dari model regresi adalah 1,895. Jadi dapat disimpulkan bahwa $\mathrm{dU}<\mathrm{d}<4-\mathrm{dU}$ yaitu $1,6148<$ $1,895<2,3852$ Dengan melihat tabel pembanding yaitu tabel Durbin Watson dan kriteria autokorelasi maka tidak ada autokorelasi positif maupun negatif.

\section{Analisis Linear Berganda}

Regresi linear berganda menjelaskan tentang hubungan antara variabel independen $(\mathrm{X})$ dan variabel dependen $(\mathrm{Y})$ berkaitan erat dengan hubungan yang bersifat statistik. Penelitian ini dilakukan untuk mengetahui arah hubungan manajemen laba dan rasio likuiditas dengan agresivitas pajak.

\section{Tabel 4.6}

\section{Hasil Analisis Linear Regresi Berganda}

Coefficients $^{a}$

\begin{tabular}{|c|c|c|c|c|c|c|}
\hline \multirow{2}{*}{\multicolumn{2}{|c|}{ Model }} & \multicolumn{2}{|c|}{ Unstandardized Coefficients } & \multirow{2}{*}{\begin{tabular}{|l|}
$\begin{array}{l}\text { Standardized } \\
\text { Coefficients }\end{array}$ \\
Beta
\end{tabular}} & \multirow[b]{2}{*}{$T$} & \multirow[b]{2}{*}{ Sig. } \\
\hline & & $B$ & Std. Error & & & \\
\hline 1 & $\begin{array}{l}\text { (Constant) } \\
\text { ML } \\
\mathrm{L}\end{array}$ & $\begin{array}{l}, 263 \\
-, 020 \\
-, 004\end{array}$ & $\begin{array}{l}, 005 \\
, 164 \\
, 001\end{array}$ & $\begin{array}{l}-, 017 \\
-, 435\end{array}$ & $\begin{array}{l}58,223 \\
-, 120 \\
-3,123\end{array}$ & $\begin{array}{l}, 000 \\
, 905 \\
, 003\end{array}$ \\
\hline
\end{tabular}

a. Dependent Variable: AP

Sumber : Hasil Output SPSS versi 22 
Berdasarkan tabel 4.6 maka dapata dibuat persamaan regresi linear berganda sebagai berikut:

Agresivitas Pajak (Y) = 0,263 - 0,020 X $\mathrm{X}^{-} 0.004 \mathrm{X}_{2}+\mathrm{e}$

Dari persamaan regresi tersebut menunjukan bahwa nilai konstanta sebesar $0,263$ jika dalam variabel independen yaitu menejeman laba( $\beta 1)$ dan likuiditas ( $\beta 2$ ) nilainya 0 maka Agresivitas pajak (Y) bernilai 0.263.

Koefisien regresi pada variabel manajemen laba $(\beta 1)$ sebesar $-0,020$, menunjukan pengaruh manajemen laba terhadap agresivitas pajak searah negatif. Menunjukan bahwa jika terjadi peningkatan manajemen laba $1 \%$ dengan variabelvariabel lainnya maka akan menurunkan agresivitas pajak sebesar $2 \%$.

Koefisien regresi likuiditas $(\beta 2)$ sebesar $-0,004$ menunjukan pengaruh likuiditas terhadap agresivitas pajak searah negatif. Menunjukan bahwa jika variabel likuiditas meningkat $1 \%$ maka agresivitas pajak akan mengalami penurunan sebesar $0.4 \%$ dengan catatan variabel lain dianggap konstan.

\section{Uji Koefisien Determinasi ( Uji Adjusted R2 )}

Tabel 4.7

Uji Koefisien Determinasi ( Uji Adjusted R2 ) Model Summary ${ }^{b}$

\begin{tabular}{|l|l|l|l|l|l|}
\hline Model & $R$ & $R$ Square & $\begin{array}{l}\text { Adjusted } \\
\text { Square }\end{array}$ & $\begin{array}{l}\text { Std. Error of } \\
\text { the Estimate }\end{array}$ & $\begin{array}{l}\text { Durbin- } \\
\text { Watson }\end{array}$ \\
\hline 1 &, $434^{\mathrm{a}}$ &, 188 &, 150 &, 01463 & 1,895 \\
\hline
\end{tabular}

a. Predictors: (Constant), $L, M L$

b. Dependent Variable: AP

Dari tabel 4.7 Hasil pengujian menunjukan besarnya koefisien korelasi berganda (R), koefisien determinasi ( $R$ Square) dan koefisien determinasi yang disesuaikan (Adjusted $R$ Square). Berdasarkan tabel model summary diatas diperoleh bahwa nilai adjusted $R$ square sebesar 0,150 . Yang mengandung pengertian pengaruh variabel independen (manajemen laba dan rasio likuiditas) dapat menjelaskan variabel dependen (agresivitas pajak) sebesar 15\% sedangkan $85 \%$ dijelaskan oleh variabel lain diluar model penelitian ini.

\section{Uji signifikan Simultan (Uji F)}

Uji statistik $\mathrm{F}$ digunakan untuk menunjukan apakah semua variabel independen mempunyai pengaruh secara simultan terhadap variabel depeden. Dalam penelitian ini variabel independen dianggap berpengaruh secara simultan terhadap variabel dependen apabila nilai siginifikan $<0,05$.

Tabel 4.8

Hasil Uji F

ANOVA $^{a}$

\begin{tabular}{|c|c|c|c|c|c|}
\hline Model & Sum of Squares & $D f$ & Mean Square & $F$ & Sig. \\
\hline Regression &, 002 & 2 &, 001 & 4,876 &, $012^{b}$ \\
\hline
\end{tabular}




\begin{tabular}{|l|l|l|l|l|l|}
\hline $\begin{array}{l}\text { Residual } \\
\text { Total }\end{array}$ &, 009 & 42 &, 000 & & \\
\hline
\end{tabular}

a. Dependent Variable: AP

b. Predictors: (Constant), $L, M L$

Berdasarkan tabel di atas menunjukan bahwa secara bersama-sama variabel independen memiliki pengaruh yang signifikan terhadap variabel dependen. Hal ini dapat dibuktikan dengan nilai $\mathrm{F}$ hitung diperoleh sebesar 4,876 dengan nilai signifikan sebesar 0,012 sedangkan $F$ tabel diperoleh dengan rumus $(\mathrm{k}: \mathrm{n}-\mathrm{k})$. $\mathrm{k}$ variabel independen $\mathrm{k}=2$ dan $\mathrm{n}$ jumlah sampel $\mathrm{n}=45$. (2:43) maka diperoleh F tabel sebesar 3,21 sehingga F Hitung > F tabel yaitu 4,876 > 3,21. Dan secara sistematik diperoleh nilai signifikasi 0,012. Karena nilai signifikasi 0,012 < Taraf signifikasi 0,05. Dengan demikian maka Ha3 diterima. Hal ini menunjukan bahwa Manajemen laba dan Rasio Likuiditas berpengaruh signifikan terhadap agresivitas pajak.

\section{Uji signifikan parameter individual (Uji t Parsial)}

Tabel 4.9

Uji t Parsial

Manajemen Laba terhadap Agresivitas Pajak

Coefficients $^{a}$

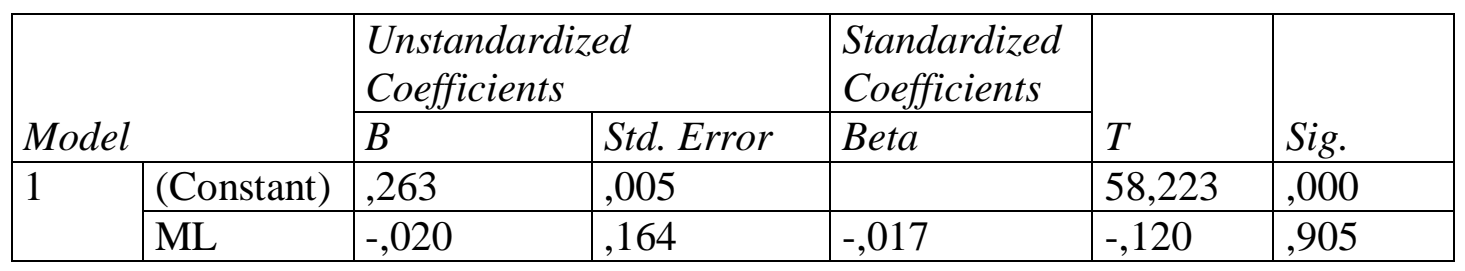

a. Dependent Variable: AP

(Sumber : Hasil Output SPSS Versi 22)

Berdasarkan hasil pengujian dari tabel 4.7 dapat disimpulkan nilai sig dari manajemen laba $>0,05(0,905>0,05)$ dan nilai $t$ tabel yang didapat dari rumus $(\alpha$ /2) ; (n-k-1) yaitu 0,$025 ; 42$ didapat hasil 2,018 dari $t_{\text {tabel }}(-0,120<2,018)$ manajemen laba lebih kecil dari $t_{\text {tabel }}$. Nilai tersebut berada diatas tingkat signifikansi yang ditentukan sebesar 0,05 sehingga dalam hal ini koefisien regresi manajemen laba tidak berpengaruh pada koefisien regresi tingkat agresivitas pajak perusahaan. Oleh karena itu $\mathrm{H}_{1}$ yang menyebutkan manajemen laba berpengaruh negatif terhadap agresivitas pajak ditolak.

Tabel 4.10

Uji t parsial

Rasio Likuiditas terhadap Agresivitas Pajak

\begin{tabular}{|c|c|c|c|c|c|}
\hline \multirow[b]{2}{*}{ Model } & \multicolumn{2}{|c|}{ Unstandardized Coefficients } & \multirow{2}{*}{$\begin{array}{l}\text { Standardized } \\
\text { Coefficients } \\
\text { Beta }\end{array}$} & \multirow[b]{2}{*}{$T$} & \multirow[b]{2}{*}{ Sig. } \\
\hline & $B$ & Std. Error & & & \\
\hline (Constant) & ,263 &, 005 & & 58,223 &, 000 \\
\hline
\end{tabular}




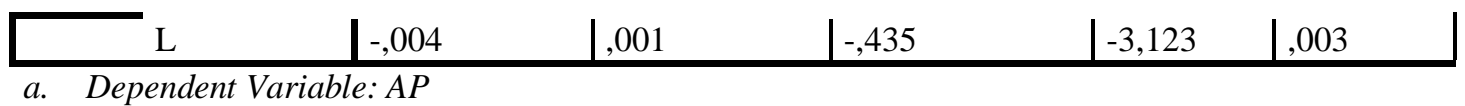

Sumber : Data output SPSS versi 22

Hasil uji t dilihat pada tabel 4.8 yang menunjukan bahwa variabel likuiditas yang diukur dengan current ratio memiliki signifikasi sebesar 0,003 yang lebih kecil dari 0,05 . Sehingga dapat disimpulkan bahwa rasio likuiditas berpengaruh signifikan terhadap tingkat agresivitas pajak.

\section{Pembahasan Hasil Penelitian}

Berdasarkan dari hasil tabel 4.8 Dapat diketahui jika variabel manajemen laba secara parsial menunjukan nilai t sebesar $-0,120$ dengan tingkat signifikasi sebesar 0,905 . Hal ini berarti $\mathrm{t}$ hitung $-0,120<2,018$ dan nilai signifikasi $0,905>$ 0,05. Dengan demikian dapat disimpulkan bahwa variabel manajemen laba tidak berpengaruh signifikan terhadap agresivitas pajak maka hipotesis $\mathrm{H}_{1}$ ditolak.

Hasil penelitian ini konsisten dengan hasil penelitian yang dilakukan oleh Risma Cahyani (2016) yang membuktikan bahwa manajemen laba tidak berpengaruh signifikan terhadap agresivitas pajak.

Berdasarkan dari hasil tabel 4.9 dapat diketahui jika variabel likuiditas secara parsial menunjukan nilai t sebesar -3,123 dengan tingkat signifikasi 0,003. Nilai signifikasi $0,003<0,05$. Dengan demikian dapat disimpulkan bahwa variabel rasio likuiditas mempunyai pengaruh negatif dan signifikan terhadap agresivitas pajak maka hipotesis $\mathrm{H}_{2}$ diterima.

Hasil penelitian ini konsisten dengan hasil penelitian yang dilakukan oleh Sri Lestari (2017) yang membuktikan bahwa likuiditas yang tinggi akan mempengaruhi perusahaan menjadi lebih agresif dalam menangani beban pajaknya karena likuiditas yang tinggi akan berpengaruh pada tingkat laba yang tinggi.

\section{Manajemen Laba dan Rasio Likuiditas terhadap Agresivitas Pajak}

Hasil uji simultan $\mathrm{F}$ menunjukan bahwa hasil $\mathrm{H} 3$ diketahui nilai $\mathrm{F}_{\text {hitung }}$ sebesar 4,876 dengan nilai signifikan sebesar 0,012 sedangkan $F_{\text {tabel }}$ diperoleh dengan rumus $(\mathrm{k}: \mathrm{n}-\mathrm{k})$. $\mathrm{k}$ sama dengan variabel independen $\mathrm{k}=2$ dan $\mathrm{n}$ jumlah sampel $\mathrm{n}=45$. (2:43) maka diperoleh $\mathrm{F}$ tabel sebesar 3,21 sehingga $\mathrm{F}$ Hitung $>$ F tabel yaitu 4,876 > 3,21. Dan secara sistematik diperoleh nilai signifikasi 0,012. Karena nilai signifikasi $0,012<$ Taraf signifikasi 0,05. Sehingga dapat disimpulkan bahwa Manajemen Laba dan Rasio Likuiditas berpengaruh positif dan signifikan terhadap Agresivitas Pajak

Maka H3 diterima.

\section{KESIMPULAN}

1. Pada uji parsial pengaruh manajemen laba terhadap agresivitas pajak di dapat bahwa manajemen laba tidak berpengaruh signifikan terhadap agresivitas pajak. 
2. Pada uji parsial pengaruh rasio likuiditas terhadap agresivitas pajak didapat bahwa likuiditas berpengaruh negatif terhadap agresivitas pajak.

3. Pada uji simultan hasil penelitian menunjukan bahwa manajemen laba dan rasio likuiditas secara bersama-sama berpengaruh positif terhadap agresivitas pajak.

\section{Keterbatasan Penelitian}

Penelitian ini dilaksanakan sesuai dengan prosedur ilmiah namun masih memiliki beberapa keterbatasan, yaitu :

1. Penelitian ini hanya berfokus pada variabel Manajemen laba dan Rasio Likuiditas, sedangkan masih banyak faktor lain yang mempengaruhi agresivitas pajak.

2. Sampel penelitian yang digunakan dalam penelitian ini hanya berfokus pada perusahaan manufaktur sektor barang konsumsi yang terdaftar di Bursa Efek Indonesia.

\section{Saran}

Adapun saran yang dapat penulis ajukan untuk penelitian-penelitian selanjutnya dibidang perpajakan, agar lebih dapat melihat tingkat agresivitas pajak pada suatu perusahaan yaitu:

1. Bagi peneliti selanjutnya, sebaiknya meneliti variabel independen lain yang dapat mempengaruhi agresivitas pajak dan menambha sampel penelitian yang lebih luas sehingga dapat memperlihatkan kegiatan-kegiatan agresivitas pajak tersebut.

2. Bagi peneliti selanjutnya disarankan untuk menggunakan sektor lain selain manufaktur sektor barang konsumsi dengan jumlah sampel dan populasi yang lebih banyak yang terdaftar di Bursa Efek Indonesia.

3. Bagi perusahaan, sebaiknya dalam pengambilan keputusan-keputusaan perusahaan lebih diperhatikan sehingga agresivitas pajak dapat lebih ditekan.

4. Bagi pemerintah hendaknya lebih meningkatkan upaya pelayanan pengawasan pada kewajiban membayar pajak perusahaan. Tujuannya agar agresivitas pajak dapat diminimalkan walaupun masih diperbolehkan dalam hukum.

\section{DAFTAR PUSTAKA}

Adisamartha, Ida Bagus Putu Fajar Dan Naniek Noviari. (2015). Pengaruh Likuiditas, Leverage, intensitas persediaan dan intensitas aset tetap pada tingkat Agresivitas Wajib Pajak Badan.

Arief, Reysky Aisyah, Dudi Pratomo, dan Vaya Juliana Dillak. (2016). Pengaruh

Manajemen Laba terhadap Agresivitas Pajak.

Agoes dan Trisnawati. (2013). Akuntansi Perpajakan.edisi 3. Jakarta:Salemba Empat. 
Belkaoui, A.R. (2007). Accounting Theory. 5th edition. Buku 2. Edisi Terjemahan.

Jakarta: Salemba Empat.

Deviana, Birgita S.P. (2010). Kemampuan Beban Pajak Tangguhan dan Beban Pajak Kini Dalam Deteksi Manajemen Laba Pada Saat Seasoned Equity Offerings.

Ghozali, imam. (2013). aplikasi analisis multivariate dengan program imb spss 22. Edisi kelima. Universitas Diponogoro. Semarang.

Harahap, Sofyan Syafri. (2011). Teori Akuntansi. Edisi revisi 2011.Jakarta: PT Raja Grafindo Persada.

Harjo, Dwikora. (2012). Perpajakan Indonesia. Mitra Wacana Media. Jakarta.

Kasmir.(2008). Analisis Laporan Keuangan. Jakarta : Raja Grifindo Persada.

Lestari, Sri. (2017). Pengaruh Likuiditas, Profitabilitas, Leverage dan Intensitas aset

tetap terhadap Agresivitas Pajak perusahaan

Mardiasmo. (2011) .Perpajakan.edisi revisi 2011. Jakarta:AndiYogyakarta.

Majid, Muhammad Ikhsan. (2017). Pengaruh Corporate Social Responsibility dan Manajemen Laba terhadap Agresivitas Pajak.

Pujiarti, Tia. (2016). Pengaruh Leverage, Manajemen Laba dan Komisaris independen terhadap Agresivitas Pajak Perusahaan.

Risma Cahyani. (2016). Pengaruh Manajemen Laba dan Corporate Social Responsibility terhadap Agresivitas Pajak.

Resmi,Siti. (2011). Perpajakan: Teori dan Kasus Edisi 6 buku 1 .Jakarta:Salemba Empat.

Resmi, Siti 2013. Perpajakan Teori dan Kasus Edisi 7. Jakarta: Salemba Empat.

Saputra, Apriani. (2017). Pengaruh perencanaan pajak dan beban pajak tangguhan

terhadap manajemen laba.

Sartono, Agus. (2014). Manajemen KeuanganTeori dan Aplikasi. Edisi empat cetakan ketujuh Yogyakarta: Penerbit BPFE.

Suandy, Erly. (2011). Hukum Pajak. Edisi 5. Jakarta: Salemba Empat.

Sugiyono, (2016). Metode Penelitian Kuantitatif, Kualitatif dan R\&D. Bandung: Alfabeta.

Sulistyanto, H. Sri. (2014). Manajemen Laba. Teori Dan Metode Empiris. Jakarta: Grasindo.

UUD 1945 pasal 23 ayat 2 Tentang pemungutan pajak.

Waluyo. (2011). Akuntansi Pajak. Penerbit Salemba Empat. Jakarta.

Wulandari, Sri. (2016). Pengaruh Manajemen Laba dan Komisaris independen terhadap Agresivitas Pajak dengan ukuran perusahaan sebagai variabel moderating.

www.idx.co.id

www.kompas.com

www.liputan6.com

Yani, Pamor Dani. (2017). Pengaruh Likuiditas, Profitabilitas, intensitas persediaan dan ukuran perusahaan terhadap tingkat agresivitas wajib pajak badan. 
Vol.2, No. 1, Jan. 2019

Yolanda, Lucy Tania. (2014). Pengaruh Likuiditas, Manajemen Laba dan Corporate

Governance terhadap Agresivitas Pajak

Yuliana, Ririn. (2016). Pengaruh Leverage dan manejemen Laba terhadap Agresivitas Pajak Perusahaan.

Yuliyanti. (2004). Kemampuan Beban Pajak Tangguhan Dalam Memprediksi Manajemen Laba. 